\title{
ПОТЕНЦИАЛ НАДЕЖНОСТИ ОБРАЗЦОВ ЯРОВОЙ ПШЕНИЦЫ ПО КОМПЛЕКСУ ПРИЗНАКОВ ДЛЯ СЕЛЕКЦИИ В УСЛОВИЯХ КРАСНОЯРСКОЙ ЛЕСОСТЕПИ
}

\author{
V.I. Nikitina, D.F. Fedosenko
}

\section{RELIABILITY POTENTIAL OF SPRING WHEAT SAMPLES BASED ON THE SET OF SIGNS FOR THE SELECTION IN KRASNOYARSK FOREST-STEPPE}

Никитина Вера Ивановна - д-р биол. наук, проф. каф. ландшафтной архитектуры и ботаники Красноярского государственного аграрного университета, г. Красноярск.

E-mail: vi-nikitina@mail.ru

Федосенко Денис Федорович - асп. каф. ландшафттнй архитектуры и ботаники Красноярского государственного аграрного университета, г. Красноярск. E-mail: day-black@mail.ru

Цель исследований: подобрать исходный материал для селекции экологически пластичных урожайных сортов мягкой яровой пшеницы, способных формировать зерно с высокими технологическими показателями, в условиях Красноярской лесостепи. Полевые опыты по изучению исходного материала 33 образцов мягкой яровой пшеницы сибирской селекции проведены в 2017-2019 г2. в ОПХ «Минино» Красноярского НИИСХ. Определение технологических показателей зерна осуществлено группой технологической оценки селекционного материала Красноярского НИИСХ. Из разбираемых показателей качества зерна наиболее стабильными являлись натура зерна, качество клейковины по ИДК-1. Высокая изменчивость была характерна для силы муки. Оm слабой до средней степени сортовое варьирование отмечено по количеству сырой клейковины, содержанию белка в зерне, стекловидности. Обработка полученных данных по методике Д.А. Сапрыгина позволила провести комплексный анализ с учетом урожайности массы 1000 зерен, содержания белка и клейковины, устойчивости к полеганию, продолжительности вегетационного периода и объективно выделить образцы пшеницы по критерию запасаемой энергии в урожае зерна и критерию их надежности. Образцы, запасающие энергию
Nikitina Vera Ivanovna - Dr. Biol. Sci., Prof., Chair of Landscape Architecture, Botany, Agroecology, Krasnoyarsk State Agrarian University, Krasnoyarsk.

E-mail: E-mail: vi-nikitina@mail.ru

Fedosenko Denis Fedorovich - Post-Graduate Student, Chair of Landscape Architecture and Botany, Krasnoyarsk State Agrarian University, Krasnoyarsk. E-mail: day-black@mail.ru

в пределах 88-95 кДж, имеют возможность занимать значительные площади посева и служить для селекционера хорошим исходным материалом для гибридизации: Красноярская 12, Алтайская 70, К-518-4, Курагинская 2, К-534-2, Новосибирская 18, Новосибирская 29, Предгорная, Омская Краса, К-527-2, Сибирский Альянс. Максимальные баллы (164-191) в разных условиях вегетации по критерию надежности имели образцы: среднеспелые - Красноярская 12, K-518-4, K-534-2, Новосибирская 18, Омская Краса, Сибирский Альянс; среднеранние - Алтайская 70, Новосибирская 29, Омская 32, Тулунская 12.

Ключевые слова: яровая пшеница, селекция, потенциал, технологические показатели качества зерна, критерий запасаемой энергии, критерий надежности.

The purpose of the research was to find the source material for the selection of ecologically plastic yielding varieties of soft spring wheat capable of forming grain with high technological indicators in the conditions of the Krasnoyarsk foreststeppe. Field experiments on the source material study of 33 samples of soft spring wheat of Siberian selection was carried out on experimental farm "Minino" Krasnoyarsk Research Institute of Agriculture in 2017-2019. The definition of grain techno- 
logical indicators was carried out by the group for technological evaluation of selection material at Krasnoyarsk Research Institute of Agriculture. From analyzed grain the most stable quality indicators were the nature of the grain, the quality of gluten according to measuring deformation of gluten 1. High variability was characteristic for the flour strength. From mild to moderate varietal variation was noted in the amount of crude gluten, the protein content in the grain, and vitreous. Processing the obtained data by the method of D.A. Saprygin made it possible to make a comprehensive analysis taking into account the yield, weight of 1000 grains, protein and gluten content, resistance to lodging, the duration of the growing season and to identify wheat samples by the criterion of stored energy in the grain yield and the criterion of their reliability. The samples storing the energy in the range of 88$95 \mathrm{~kJ}$ have the ability to occupy significant areas of sowing and to serve as a good source for hybridization: Krasnoyarskaya 12, Altayskaya 70, K-518-4, Kuraginskaya 2, K-534-2, Novosibirskaya 18, Novosibirskaya 29, Predgornaya, Omskaya Krasa, K-527-2, and Siberian Alliance. The maximum points (164-191) in different vegetation conditions according to the reliability criterion were received by the samples: mid-ripening varieties - Krasnoyarskaya 12, K-518-4, K-534-2, Novosibirskaya 18, Omskaya Krasa, Siberian Alliance; medium-early varieties - Altayskaya 70, Novosibirskaya 29, Omskaya 32, Tulunskaya 12.

Keywords: spring wheat, selection, potential, technological indicators of grain quality, stored energy criterion, reliability criterion.

Введение. Успех селекционной работы определяется наличием хорошо изученного исходного материала. Как показали результаты исследований, оценка образцов яровой мягкой пшеницы только по урожайности и элементам ее структуры, параметрам стабильности явно недостаточна. Выделившиеся образцы по данным количественным признакам могут проигрывать из-за неустойчивости к полеганию по технологическим качествам зерна и муки, продолжительности вегетационного периода. Объективность выбора сортов для условий сельскохозяйственного производства, наряду с оценкой их по экологической стабильности, предполагает окончательную их оценку по оптимальности сочетания показателей количества и качества урожая. В связи с этим приобретают актуальность комплексные исследования потенциала образцов яровой пшеницы сибирской селекции в условиях Красноярской лесостепи.

Цель исследований. Подобрать исходный материал для селекции экологически пластичных урожайных сортов мягкой яровой пшеницы, способных формировать зерно с высокими технологическими показателями в условиях Красноярской лесостепи.

Задачи исследований: оценка образцов пшеницы по совокупности признаков: урожайности, скороспелости, устойчивости к полеганию, технологическим показателям качества зерна; выявление образцов пшеницы, стабильно сохраняющих высокую урожайность, с комплексом хозяйственно ценных признаков при различных условиях вегетации.

Материал и методы исследований. В 2017-2019 гг. в ОПХ «Минино» Красноярского НИИСХ ФИЦ КНЦ СО РАН были проведены опыты по оценке исходного материала - 33 образцов мягкой яровой пшеницы сибирской селекции. Стандартные сорта распределены по группам спелости: раннеспелые, среднеранние - Алтайская 70; среднеспелые - Алтайская 75; среднепоздние - Свирель. Посев образцов пшеницы выполняли по чистому пару в оптимальные для Красноярской лесостепи сроки (17-20 мая) сеялкой ССФК-7 в четырехкратной повторности с нормой высева 500 всхожих зерен на $1 \mathrm{~m}^{2}$. Площадь делянок $-3,26 \mathrm{~m}^{2}$, учетная $-3 \mathrm{M}^{2}$.

Закладку опытов, учеты и наблюдения осуществляли в соответствии с методикой государственного сортоиспытания сельскохозяйственных культур $[1,2]$ и методическими указаниями ВНИИР по изучению мировой коллекции пшеницы [3].

Технологический анализ зерна совершен группой технологической оценки селекционного материала Красноярского НИИСХ.

Результаты исследований и их обсуждение. Из 6 исследуемых показателей качества зерна наиболее стабильными являлись натура зерна, качество клейковины по ИДК-1 (табл. 1). По этим признакам у образцов яровой пшеницы наблюдались сравнительно небольшие отклонения от средних значений по опыту. 


\section{Межсортовое варьирование показателей качества зерна}

(2017-2019 гг.)

\begin{tabular}{|l|c|c|c|c|}
\hline \multicolumn{1}{|c|}{ Показатель качества } & Изменчивость & $\begin{array}{c}\text { Средняя по } \\
\text { опыту }\end{array}$ & $\begin{array}{c}\text { Коэфрфициент } \\
\text { вариации, \% }\end{array}$ & $\begin{array}{c}\text { Средний по } \\
\text { опыту, \% }\end{array}$ \\
\hline Натура зерна, г/л & $690-804$ & 763 & $1,4-2,7$ & 1,6 \\
Стекловидность, \% & $18-56$ & 44 & $6,3-19,7$ & 11,7 \\
Содержание белка, \% & $9,22-16,14$ & 12,43 & $7-12,1$ & 9,0 \\
Количество клейковины, \% & $14,3-36,8$ & 26,5 & $11,1-17,2$ & 14,3 \\
Качество клейковины & $60-92$ & 76,5 & $6,0-10,1$ & 8,0 \\
по ИДК-1, ед. & - & - & - & - \\
Сила муки, е.а. & $192-697$ & 404 & $27,5-29,4$ & 28,8 \\
\hline
\end{tabular}

Высокая изменчивость характерна для силы муки. От слабой до средней степени сортовое варьирование отмечено по количеству сырой клейковины, содержанию белка в зерне, стекловидности.

Натура зерна косвенно характеризует его выполненность. Такое зерно содержит больше эндосперма. Шесть образцов пшеницы соответствовали 1-му классу, их натура превышала 750 г/л: Красноярская 12, Алтайская 75, Руслада, Уярочка, К-527-2, Свирель. У 13 образцов натура зерна была выше 730 г/л. Только 4 образца в 2017 г. имели натуру зерна ниже 710 г/л: Зоряна, Омская 32, Сигма 2, К-626-1. Стекловидность зерна считается косвенным показателем для оценки содержания белка, его мукомольных и хлебопекарных свойств. Ни у одного образца пшеницы в изучаемые годы стекловидность зерна не превышала 60 \%. Среднюю стекловидность зерна (40-59 \%) имели 13 образцов: Новосибирская 15, Канская, Чулымская, Новосибирская 14, Алтайская 70, Скала, Тулунская 12, Новосибирская 29, Новосибирская 31, Памяти Вавенкова, Руслада, К-518-4, Предгорная.

Важным показателем качества зерна являются не только питательность, технологические и мукомольно-хлебопекарные качества, но и содержание белка в зерне. Из изучаемой группы не выявлено ни одного образца, сохраняющего способность формировать его высокое содержание (более 14,0 \%) в различных условиях вегетации. Особенно низкое содержание белка отмечено в 2019 г., оно варьировало от 9,22 до $12,34 \%$, что соответствовало по ограничительным нормам для мягкой пшеницы 3-5-м классам. Снижение доли белка связано с погодными условиями, сложившимися в период вегетации растений, а именно в период формирования и налива зерна. По массовой доле белка только 5 образцов из группы раннеспелых и среднеранних в 2019 г. соответствовали 3-му классу: Новосибирская 15, Чулымская, Новосибирская 14, Алтайская 70, Тулунская 12.

Содержание клейковины определяет упругость, эластичность и вкусовые качества хлеба. Только один сорт, Новосибирская 31, в годы изучения сохранил долю сырой клейковины на уровне 1-го и 2-го класса. Не снижали уровня 3-го класса содержания клейковины 8 сортов: Новосибирская 15, Чулымская, Новосибирская 14 , Алтайская 70, Тулунская 12, Новосибирская 29, Памяти Вавенкова, Руслада. Шесть образцов имели в разных условиях вегетации хорошую по качеству клейковину (60-77 ед. прибора ИДК-1): Красноярская 12, К-527-2, Сигма 2, К-626-1, К-592-5, К-613-2. Удовлетворительная слабая по качеству клейковина была у остальных сортов пшеницы.

Сила пшеничной муки зависит от количества и качества клейковины, содержащейся в муке. Для селекции на качество представляют образцы, имеющие силу муки более 280 е.а., сохраняющие это свойство в различных условиях выращивания. Требованиям сильной пшеницы по этому показателю соответствовали 20 образцов пшеницы: Новосибирская 15, Канская, Чулымская, Зоряна, Новосибирская 14, Алтайская 70, Скала, Тулунская 12, Новосибирская 31, Памяти Вавенкова, Руслада, Уярочка, Омская 32, Алтайская 75, Сибирский Альянс, Новосибирская 18, Курагинская 2, К-524-2, К-527-2, Сигма 2. Силу ниже 260 е.а. в годы исследований показали 2 образца: К-592-5, К-613-2. 
Особое значение имеют методики, позволяющие оценить образцы пшеницы по урожайности, массе 1000 зерен, технологическим качествам, устойчивости к полеганию и продолжительности вегетационного периода. Такая методика была предложена Д.А. Сапрыгиным $[4,5]$. Он рекомендовал уровень экологической пластичности определять по формуле

$$
K=\left[\left(X_{1} \cdot X_{2}\right)+\left(X_{1} \cdot X_{3}\right)+X_{4}\right] \cdot X_{5} / X_{6} \cdot X_{7}
$$

где К - критерий надежности, пластичности сорта; $X_{1}$ - урожайность зерна; $X_{2}$ - содержание белка; $\mathrm{X}_{3}$ - содержание клейковины; $\mathrm{X}_{4}$ - масса 1000 зерен; $X_{5}$ - устойчивость к полеганию; $X_{6}$ вегетационный период; $X_{7}$ - условный коэффиициент усиления, равный 5 .

Другой критерий дозволяет оценить надежность сортов для производства по количеству запасенной энергии в зерновом белке за день вегетационного периода

$$
\mathrm{K}=\mathrm{Y}_{3}: 100 \cdot \text { Уб } \cdot 4: \mathrm{B} \sqcap \cdot 4,19,
$$

где К - критерий запасенной энергии, кДж;

Уз - урожайность зерна, кг/га; 100 - урожайность с 1 га, \%;

Уб - содержание белка в зерне, \%;

4 - коэффицциент пересчета белка пшеницы в килокалории;

Вп - вегетационный период, дней;

4,19 - коэфффициент пересчета килокалорий в единицы измерения энергии, кДж.
Этот метод Д.А. Сапрыгин советует использовать для предварительной оценки сортов при комплектовании питомника конкурсного испытания. Положительное решение следует принимать при условии, если величина критерия сорта, кандидата в конкурсное испытание, превышает эталон (стандарт) не менее чем на 4,19 кДж/день.

Критерий запасаемой энергии, рассчитанный для образцов разных групп спелости, находился в пределах 58-96,6 кДж (табл. 2). В группе среднеранних образцов по сравнению со стандартом по критерию запасаемой энергии не выделился ни один образец. В группе среднеспелых образцов основное их число имеет критерий запасаемой энергии выше стандарта, нужно особенно отметить Красноярскую 12, К-518-4, Курагинскую 2, К-534-2, Новосибирскую 18, Предгорную, Омскую Красу, К-527-2, Сибирский Альянс. По критерию запасаемой энергии интерес для селекции представляет среднеранний сорт Алтайская 70, у которого эти показатели почти на уровне Красноярской 12. Среднепоздние образцы не проявили по изучаемому критерию лучших значений в сравнении со стандартом.

По критерию надежности, способности сохранять более высокую урожайность, технологические качества в меняющихся условиях вегетации более высокие баллы имели: среднеспелые образцы - Красноярская 12, К-518-4, К-534-2, Новосибирская 18; среднеранние - Алтайская 70, Новосибирская 29.

Таблица 2

\begin{tabular}{|c|c|c|c|c|c|c|}
\hline Образец & $\begin{array}{c}\text { Группа } \\
\text { спелости* }\end{array}$ & 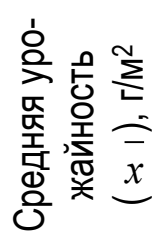 & 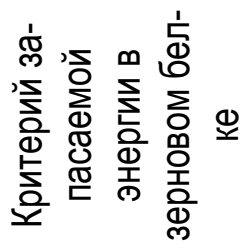 & 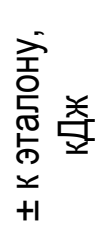 & 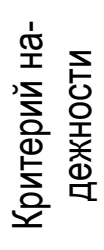 & 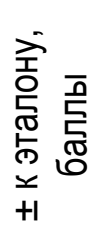 \\
\hline 1 & 2 & 3 & 4 & 5 & 6 & 7 \\
\hline Алтайская 70, st. & 04 & 308,3 & 94,8 & st. & 184 & st. \\
\hline Новосибирская 15 & 03 & 192,8 & 65,4 & $-29,4$ & 128 & -56 \\
\hline Канская & 04 & 228,5 & 70,1 & $-24,7$ & 137 & -47 \\
\hline Чулымская & 04 & 209,2 & 69,0 & $-25,8$ & 134 & -50 \\
\hline Зоряна & 04 & 228,6 & 72,8 & $-22,0$ & 136 & -48 \\
\hline Новосибирская 14 & 04 & 179,0 & 58,0 & $-36,8$ & 120 & -64 \\
\hline
\end{tabular}

Оценка надежности образцов яровой пшеницы на основе функционального критерия 
Вестник КрасТАY. 2020. № 4

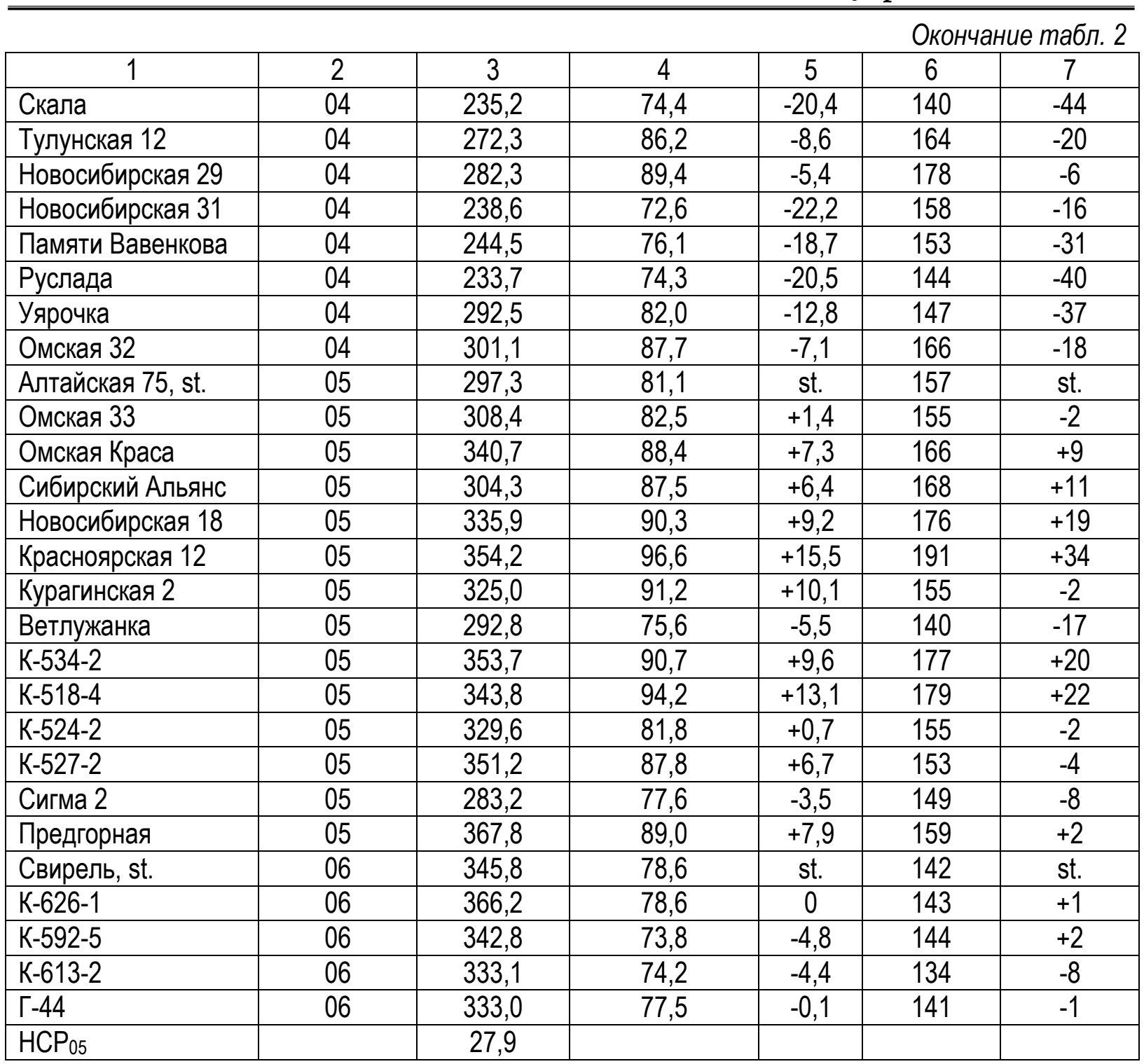

"03 - раннеспелые; 04 - среднеранние; 05 - среднеспелые; 06 - среднепоздние сорта.

На уровне среднеспелых образцов Омская Краса, Сибирский Альянс лучшие баллы показали среднеранние сорта: Омская 32, Тулунская 12. Повышение критерия надежности у этих сортов связано с лучшими показателями по содержанию белка, клейковины, массы 1000 зерен, более коротким вегетационным периодом.

Такие образцы, как Предгорная, К-626-1, К-527-2, К-592-5, выделившиеся по средней урожайности, комплексной оценке, проявили резкое снижение данного показателя. Понижение его произошло из-за низкого содержания белка, клейковины, большей продолжительности вегетационного периода.

Заключение. Объективность оценки сортов зависит от сочетания количественных признаков урожайности и технологических показателей зерна.

По критерию запасаемой энергии в урожае зерна для селекции пшеницы в Восточной Сибири представляют интерес следующие образцы: Красноярская 12, Алтайская 70, К-518-4, Курагинская 2, К-534-2, Новосибирская 18, Новосибирская 29, Предгорная, Омская Краса, К527-2, Сибирский Альянс. Повышенным критерием надежности на уровне 164-191 баллов в разных условиях вегетации характеризовались образцы: среднеспелые - Красноярская 12, К518-4, К-534-2, Новосибирская 18; среднеранние - Алтайская 70, Новосибирская 29. 
Литература

1. Методика государственного сортоиспытания сельскохозяйственных культур (общая часть) / под ред. М.А. Федина Вып. 1. М.: Колос, 1985. 269 с.

2. Методика государственного сортоиспытания сельскохозяйственных культур. Вып. 2: Зерновые, крупяные, зернобобовые, кукуруза и кормовые культуры / ред. А.И. Григорьева. М.: Колос, 1989. 194 с.

3. Руденко М.И., Шитова И.П., Корнейчук В.А. Методические указания по изучению мировой коллекции пшеницы / под ред. В.Ф. Дорофреева. 3-е изд., перераб. Л.: ВИР, 1977. $28 \mathrm{c}$.

4. Сапрыгин Д.А. Метод фуннцционального критерия надежности сортов яровой пшеницы для массового производства: метод. Рекомендации / под ред. Р.А. Цильке. Новосибирск: СО ВАСХНИЛ, 1984. 37 с.

5. Сапрьгин Д.А. Методы оценки сортов яровой пшеницы по критерию интенсивности и нормативы их ускоренного внедрения в производство Западной Сибири: автореф. дис. ... канд. С.-х. наук. Новосибирск, 1987. 18 с.

\section{Literatura}

1. Metodika gosudarstvennogo sortoispytanija sel'skohozjajstvennyh kul'tur (obshhaja chast') I pod red. M.A. Fedina Vyp. 1. M.: Kolos, 1985. $269 \mathrm{~s}$.

2. Metodika gosudarstvennogo sortoispytanija sel'skohozjajstvennyh kul'tur. Vyp. 2: Zernovye, krupjanye, zernobobovye, kukuruza i kormovye kul'tury / red. A.l. Grigor'eva. M.: Kolos, 1989. $194 \mathrm{~s}$.

3. Rudenko M.I., Shitova I.P., Kornejchuk V.A. Metodicheskie ukazanija po izucheniju mirovoj kollekcii pshenicy / pod red. V.F. Dorofeeva. 3-e izd., pererab. L.: VIR, 1977. $28 \mathrm{~s}$.

4. Saprygin D.A. Metod funkcional'nogo kriterija nadezhnosti sortov jarovoj pshenicy dlja massovogo proizvodstva: metod. Rekomendacii / pod red. R.A. Cil'ke. Novosibirsk: SO VASHNIL, 1984. $37 \mathrm{~s}$.

5. Saprygin D.A. Metody ocenki sortov jarovoj pshenicy po kriteriju intensivnosti i normativy ih uskorennogo vnedrenija $\mathrm{v}$ proizvodstvo Zapadnoj Sibiri: avtoref. dis. ... kand. s.-h. nauk. Novosibirsk, $1987.18 \mathrm{~s}$. 